\title{
Article
}

\section{Residual Helicity at the Active Site of the Histidine Phosphocarrier, HPr, Modulates Binding Affinity to Its Natural Partners}

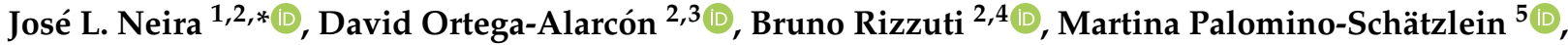 \\ Adrián Velázquez-Campoy ${ }^{2,3,6,7,8}$ (i) and Alberto Falcó ${ }^{1}$ (i)
}

check for updates

Citation: Neira, J.L.; Ortega-Alarcón, D.; Rizzuti, B.; Palomino-Schätzlein, M.; Velázquez-Campoy, A.; Falcó, A. Residual Helicity at the Active Site of the Histidine Phosphocarrier, HPr, Modulates Binding Affinity to Its Natural Partners. Int. J. Mol. Sci. 2021, 22, 10805. https://doi.org/ 10.3390/ijms221910805

Academic Editor: Vladimir N. Uversky

Received: 13 September 2021

Accepted: 2 October 2021

Published: 6 October 2021

Publisher's Note: MDPI stays neutral with regard to jurisdictional claims in published maps and institutional affiliations.

Copyright: (c) 2021 by the authors. Licensee MDPI, Basel, Switzerland. This article is an open access article distributed under the terms and conditions of the Creative Commons Attribution (CC BY) license (https:/ / creativecommons.org/licenses/by/ $4.0 /)$.
1 IDIBE, Universidad Miguel Hernández, 03202 Elche, Spain; alber.falco@umh.es

2 Joint Units IQFR-CSIC-BIFI, and GBsC-CSIC-BIFI, Instituto de Biocomputación y Física de Sistemas Complejos (BIFI), Universidad de Zaragoza, 50018 Zaragoza, Spain; dortega@bifi.es (D.O.-A.); bruno.rizzuti@cnr.it (B.R.); adrianvc@unizar.es (A.V.-C.)

3 Departamento de Bioquímica y Biología Molecular y Celular, Universidad de Zaragoza, 50009 Zaragoza, Spain

4 CNR-NANOTEC, SS Rende (CS), Department of Physics, University of Calabria, Via P. Bucci, Cubo 31 C, 87036 Rende, Italy

5 Centro de Investigación Príncipe Felipe, Calle Eduardo Primo Yufera 3, 46022 Valencia, Spain; mpalomino@cipf.es

6 Instituto de Investigación Sanitaria Aragón (IIS Aragón), 50009 Zaragoza, Spain

7 Centro de Investigación Biomédica en Red en el Área Temática de Enfermedades Hepáticas y Digestivas (CIBERehd), 28029 Madrid, Spain

8 Fundacion ARAID, Government of Aragon, 50009 Zaragoza, Spain

* Correspondence: jlneira@umh.es; Tel.: +34-966-658-459

\begin{abstract}
The phosphoenolpyruvate-dependent phosphotransferase system (PTS) modulates the preferential use of sugars in bacteria. The first proteins in the cascade are common to all organisms (EI and HPr). The active site of HPr involves a histidine (His15) located immediately before the beginning of the first $\alpha$-helix. The regulator of sigma D (Rsd) protein also binds to HPr. The region of HPr comprising residues Gly9-Ala30 $\left(\mathrm{HPr}^{9-30}\right)$, involving the first $\alpha$-helix (Ala16-Thr27) and the preceding active site loop, binds to both the N-terminal region of EI and intact Rsd. $\mathrm{HPr}^{9-30}$ is mainly disordered. We attempted to improve the affinity of $\mathrm{HPr}^{9-30}$ to both proteins by mutating its sequence to increase its helicity. We designed peptides that led to a marginally larger population in solution of the helical structure of $\mathrm{HPr}^{9-30}$. Molecular simulations also suggested a modest increment in the helical population of mutants, when compared to the wild-type. The mutants, however, were bound with a less favorable affinity than the wild-type to both the N-terminal of EI (EIN) or Rsd, as tested by isothermal titration calorimetry and fluorescence. Furthermore, mutants showed lower antibacterial properties against Staphylococcus aureus than the wild-type peptide. The refore, we concluded that in HPr, a compromise between binding to its partners and residual structure at the active site must exist to carry out its function.
\end{abstract}

Keywords: binding; circular dichroism; peptides; isothermal titration calorimetry; NMR; fluorescence

\section{Introduction}

The survival of bacteria is based on their capacity to sense variations in their environments and, as a response, to adapt their metabolic systems by turning on/off the expression of specific genes [1,2]. One of those sensory systems is the bacterial phosphoenolpyruvate (PEP) sugar-dependent one, the so-called PEP-dependent phosphotransferase system (PTS). The PTS controls the preferential use of carbon sources in bacteria [3,4]. It is involved in the transport and release of carbohydrates (PTS sugars) through the cell external membrane; furthermore, the PTS also intervenes in the movement of bacteria towards carbon sources (chemotaxis) in nitrogen metabolism and in regulation of other metabolic pathways in 
both Gram-negative and Gram-positive bacteria [2,5,6]. The regulation of such pathways occurs through phosphorylation of its target proteins, and by interaction between the phosphorylated proteins. The target proteins of $\mathrm{HPr}$ can be signal transductors, transporters, catabolic enzymes, and in many cases, transcriptional regulators [5-8]. The organization of the PTS is similar in all bacterial species described so far: it is formed by a sequence of phosphoryl-transfer steps occurring through several proteins, from PEP to the sugarspecific enzyme II permeases (EIIs). The first two proteins in the cascade are common to all PTS substrates (the so-called "general PTS proteins"): the phosphocarriers EI and HPr, where phosphorylation occurs at some specific histidine residues. The 64-kDa protomer of EI protein, in all the species described so far, exhibits a dimer-monomer equilibrium. The proteolytic cleavage of the EI of Escherichia coli yields two domains [9], which also have been observed in different EI from other species [9-12]. The N-terminal domain of EI, EIN, roughly comprises the first 230 residues of the intact EI: it contains the HPr-binding domain including the active-site histidine $[13,14]$, and forms a four-helix bundle. The structure of HPr is an open-face beta-sandwich formed by three $\alpha$-helices packed against a four-stranded $\beta$-sheet [15]. The active site of HPr is located close to the $\mathrm{N}$-terminal end, and is formed by a single residue, His15, just immediately before the N-cap of the first $\alpha$-helix. His15 undergoes a PEP-dependent phosphorylation by the action of EI at the first step of the PTS. The helix nearby His15, together with the preceding loop, is the region involved in the binding to EIN (Figure S1).

Bacteria also respond to changes by modulation of the function of their transcription machinery. Transcription in bacteria is carried out by a single multi-subunit RNA polymerase (RNAP). RNAP binds to one of the $\sigma$ factors with a specific promoter recognition activity [16]. Bacterial $\sigma$ factors are multidomain proteins, including different domains that recognize specific promoter elements [17]. Bacteria have several $\sigma$ factors; for instance, in E. coli there are seven factors required for the transcription of more specialized genes $[18,19]$. The anti- $\sigma$ factor of $\sigma^{70}$ is the 158-residue-long protein Rsd (regulator of sigma D), which prevents the transcription of $\sigma^{70}$-dependent promoters [20,21]. It has been shown that the dephosphorylated form of HPr in E. coli also binds tightly to Rsd, inhibiting the formation of the complex between Rsd and $\sigma^{70}[22,23]$. The binding region of HPr involves the same one intervening in the binding to EIN [23]. We have recently shown that the Rsd from E. coli, Rsd ${ }^{\mathrm{ec}}$ (P0AFX4), is capable of binding HPr from Streptomyces coelicolor, $\mathrm{HPr}^{\mathrm{sc}}$ [24]. In S. coelicolor, there are as many as $65 \sigma$ factors, and the interaction of any of their anti- $\sigma$ factors with $\mathrm{HPr}^{\mathrm{sc}}$ has not yet been identified [25].

Streptomyces is an actinomycete, Gram-positive organism with high content of G + C base pairs in its genome. We have carried out an extensive description of the structures and conformational stabilities of $\mathrm{HPr}^{\mathrm{sc}}(\mathrm{O} 50515)$ and $\mathrm{EI}\left(\mathrm{EI}^{\mathrm{Ic}}\right)$ (Q9KZP1) to understand their binding in the PTS cascade [11,12,26,27]. We have also characterized the interaction of $\mathrm{EI}^{\mathrm{sc}}$ with wild-type $\mathrm{HPr}^{\mathrm{sc}}$ [28] and that of the phosphorylated species [29], as well as that of the N-terminal domain of $\mathrm{EI}^{\mathrm{sc}}\left(\mathrm{EIN}^{\mathrm{sc}}\right)$ with intact $\mathrm{HPr}^{\mathrm{sc}}[10,29]$. We have also shown that the peptide comprising residues Ala9-Gly30 of $\mathrm{HPr}^{\mathrm{sc}}\left(\mathrm{HPr}^{9-30}\right)$ is mainly disordered in aqueous solution (with about $7 \%$ of helical population) [30]. The peptide binds to the intact $\mathrm{EI}^{\mathrm{sc}}$ [28] with a $K_{\mathrm{d}}$ of $230 \mu \mathrm{M}$, and to EIN ${ }^{\mathrm{sc}}$ with a $K_{\mathrm{d}}$ of $8 \mu \mathrm{M}$ (both measured by isothermal titration calorimetry (ITC)) [31]. The latter value was similar to that measured for the binding reaction between intact $\mathrm{HPr}^{\mathrm{sc}}$ and $\mathrm{EIN}^{\mathrm{sc}}(12 \mu \mathrm{M}$ [31]). In addition, Rsd binds to $\mathrm{HPr}^{9-30}$ with a $K_{\mathrm{d}}$ of $2.5 \mu \mathrm{M}$, which is also similar to that measured for the intact $\mathrm{HPr}^{\mathrm{sc}}, 2 \mu \mathrm{M}$ [24] (again, as measured by ITC).

In the present work, we wondered whether an increase in the affinity for both EIN and Rsd could be obtained by increasing the helicity of isolated $\mathrm{HPr}^{9-30}$ (the peptide that contains the first $\alpha$-helix of the protein, encompassing residues Ala16-Thr27). To that aim, and by gathering indications obtained by comparing sequences of different species for HPr, we mutated residues Pro18, Ile21, Phe22, and Val23 of the wild-type sequence to Ala, obtaining at the end six different peptides (including a triple- and quadruple-mutant, in addition to the wild-type $\mathrm{HPr}^{9-30}$ ). The rationale behind the mutations in the wild-type 
sequence was the following. Although the Pro residue is highly conserved among the HPr species, the mutant P18A was designed because proline is a well-known helix-breaker [32], and we wanted to evaluate the effect of increasing the length of the helix at its $\mathrm{N}$ terminus. The residue Ile21 was mutated because this position is occupied by Leu or Cys in HPr from other species, therefore variability in this position is tolerated. Similarly, the F22A mutant was designed because the preferred residue at this position is Leu or Ile in other variants. Finally, Val23 is more frequently an Ala residue in other species. The se residues do not make a large number of contacts with either EIN or Rsd in the complexes of the whole HPr. Our results showed that, in all mutants, the helicity was slightly increased compared to the wild-type sequence, as measured by far-UV (ultraviolet) CD (circular dichroism). NMR in aqueous solution of the peptides also suggested a slight increase of the helicity in the peptides; moreover, in the presence of the organic solvent 2,2,2-trifluoroethanol (TFE), the helical structure of the peptides comprised the same residues as in the intact, wild-type protein (that is, Ala16-Thr27). However, the mutation of any of the abovementioned residues yielded a lower affinity than the wild-type peptide towards both target proteins. Furthermore, antibacterial activity against Staphylococcus aureus decreased in all the mutants, when compared to that of the wild-type sequence. The refore, there is a subtle balance between residual helicity of HPr and binding affinity towards both EIN and Rsd, which is altered by any of the mutations explored.

\section{Results}

\subsection{The Peptides Were Disordered Monomers in Aqueous Solution}

As a preliminary step towards the aim to assess the ability of peptides for binding to $\mathrm{Rsd}^{\mathrm{ec}}$ and EIN ${ }^{\mathrm{sc}}$, we firstly biophysically characterized them by using far-UV CD and NMR. The latter technique allowed us to assign the proton resonances of the peptides. Peptides were named according to their mutations compared to the wild-type sequence.

The far-UV CD spectrum of the wild-type peptide in aqueous solution has been previously described [30]. The far-UV CD spectra of the mutants showed similar features, with an intense band at $198 \mathrm{~nm}$, suggesting that the peptides were mainly disordered in aqueous solution (Figure S2) [33-35]. We used two different procedures to estimate the percentage of helical structure in the peptides. Firstly, from the ellipticity at $222 \mathrm{~nm}$, $[\Theta]^{222}$, we could estimate the percentage of helical structure [36], assuming that the value of $[\Theta]^{222}$ for a fully formed $\alpha$-helix was $-39,500 \mathrm{deg} \mathrm{cm} \mathrm{dmol}^{-1}$. The results (Table 1) indicated that, except for the I21A peptide, the mutants had a larger value of the $[\Theta]^{222}$, and therefore a larger value of helicity than the wild-type one (Table 1). This result was not entirely surprising, because the mutations introduced a larger number of residues of alanine, which is a well-known helix-inducer [32]. However, it is important to keep in mind that the findings from the molar ellipticity can be affected by the presence of aromatic residues, which also absorb at this wavelength [33-35]. Secondly, TFE titrations followed by $C D$ were employed to estimate the equilibrium constant $(K)$ for the disordered $\leftrightarrow$ helical transition reaction [37,38], assuming that there were no intermediates (as suggested by the presence of an isodichroic wavelength for each peptide titration). Unlike the above analyses on helicity, which made assumptions about how the ellipticity signal at $222 \mathrm{~nm}$ related to secondary structure content, TFE titration allowed the determination of helical content derived from the free-energy change of such equilibrium (disordered $\leftrightarrow$ helical). The $[\Theta]^{222}$ increased in absolute value for all peptides as TFE concentration was raised (Figure 1). The slopes of the titration curves at the beginning and the end of the sigmoidal transitions indicated that the population of disordered peptide confirmations (low TFE concentrations) or folded conformations (high TFE concentrations) was changing, although in a non-cooperative manner, as the concentration of co-solvent was varied. The titrations for all the peptides showed a similar cooperativity, with $m$-values ranging from 150 to $220 \mathrm{cal} /(\mathrm{mol} \%(v / v))($ Table 1$)$; although for the peptide I21A, the $m$-value was slightly lower $(130 \mathrm{cal} /(\mathrm{mol} \%(v / v)))$. The large value of this parameter found for all the peptides indicated that the transition (disordered $\leftrightarrow$ helical) was very cooperative. On the other 
hand, the $[\mathrm{TFE}]_{1 / 2}$-value (the midpoint of the transition is given in $\%(v / v)$ ) did not differ significantly among all the peptides, ranging from 19 to $24 \%(v / v)$ (Table 1 , Figure 1 ). The se values yielded a similar free energy for the disordered $\leftrightarrow$ helical reaction for most of the peptides (except for I21A), and therefore a low population (lower than $1 \%$ in all peptides) of helical structures, in contrast to what was obtained from the value of the molar ellipticity at $222 \mathrm{~nm}$, where an increase in the content of alanine residues resulted in a larger helicity. Furthermore, not only the absolute values of the helical populations were lower than those obtained from the value of $[\Theta]^{222}$, but hose with a lower helical population were I21A and V23A (that is, those with the largest free-energy value for the disordered $\leftrightarrow$ helical reaction) (Table 1). It is interesting to note here that similar $m$ - and $[\mathrm{TFE}]_{1 / 2}$-values, within the error, were previously obtained for the titration of the wild-type peptide under slightly different conditions (in phosphate buffer, pH 7.0, $10 \mathrm{mM}$ ) [30].

Table 1. Helical populations of $\operatorname{HPr}^{9-30}$ peptides as measured by far-UV CD.

\begin{tabular}{|c|c|c|c|c|}
\hline Peptide $^{\text {a }}$ & Helicity $(\%)^{a}$ & {$[\mathrm{TFE}]_{1 / 2}(\%(v / v))^{\mathrm{b}}$} & $\begin{array}{l}m \mathrm{cal} / \mathrm{mol} \\
(\%(v / v))^{b}\end{array}$ & $\Delta G^{\text {water }}(\mathrm{kcal} / \mathrm{mol})^{\mathrm{c}}$ \\
\hline G9'WAEGLHARPASIFVRAATATG (wild-type) & $1.6(-612.44)$ & $23.2 \pm 0.5$ & $166 \pm 23$ & $3.8 \pm 0.5(0.10 \%)$ \\
\hline $\mathrm{G}^{9}$ WAEGLHARAASIFVRAATATG (P18A) & $2.9(-1135.47)$ & $19.8 \pm 0.4$ & $181 \pm 17$ & $3.6 \pm 0.3(0.15 \%)$ \\
\hline $\mathrm{G}^{9}$ WAEGLHARPASIAVRAATATG (F22A) & $0.2(-84.95)$ & $22 \pm 1$ & $134 \pm 27$ & $2.9 \pm 0.6(0.5 \%)$ \\
\hline $\mathrm{G}^{9}$ WAEGLHARPASAFVRAATATG (I21A) & $1.7(-681.95)$ & $23.8 \pm 0.4$ & $197 \pm 20$ & $4.7 \pm 0.5(0.02 \%)$ \\
\hline $\mathrm{G}^{9}$ WAEGLHARPASIFARAATATG (V23A) & $2.5(-988.51)$ & $22.7 \pm 0.3$ & $217 \pm 23$ & $4.9 \pm 0.5(0.01 \%)$ \\
\hline $\begin{array}{c}\mathrm{G}^{9} \text { WAEGLHARAASAFARAATATG } \\
(\mathrm{P} 18 \mathrm{~A} / \mathrm{I} 21 \mathrm{~A} / \mathrm{V} 23 \mathrm{~A})\end{array}$ & $6.8(-2698.61)$ & $19.0 \pm 0.9$ & $184 \pm 32$ & $3.5 \pm 0.6(0.17 \%)$ \\
\hline $\begin{array}{l}\mathrm{G}^{9} \text { WAEGLHARAASAAARAATATG } \\
(\mathrm{P} 18 \mathrm{~A} / \mathrm{I} 21 \mathrm{~A} / \mathrm{F} 22 \mathrm{~A} / \mathrm{V} 23 \mathrm{~A})\end{array}$ & $18.4(-7305.73)$ & $21 \pm 1$ & $157 \pm 26$ & $3.3 \pm 0.6(0.24 \%)$ \\
\hline
\end{tabular}

${ }^{a}$ Obtained at $5{ }^{\circ} \mathrm{C}$ from the value of the $[\Theta]^{222}$, which is indicated within parentheses, and assuming that a fully formed $\alpha$-helix had a $[\Theta]^{222}$ of $-39,500 \mathrm{deg} \mathrm{cm}^{2} \mathrm{dmol}^{-1}$. ${ }^{\mathrm{b}}$ Obtained from the fitting of the TFE titration curves to a two-state equation [37,38]. Reported uncertainties are fitting errors to such equation. ${ }^{c}$ Calculated from the product of the $m$ - and $[\mathrm{TFE}]_{1 / 2}$ values. Uncertainties in the Gibbs energy were obtained from error propagation. The values within the parentheses indicate the percentage of helical population, assuming a two-state conformational equilibrium.
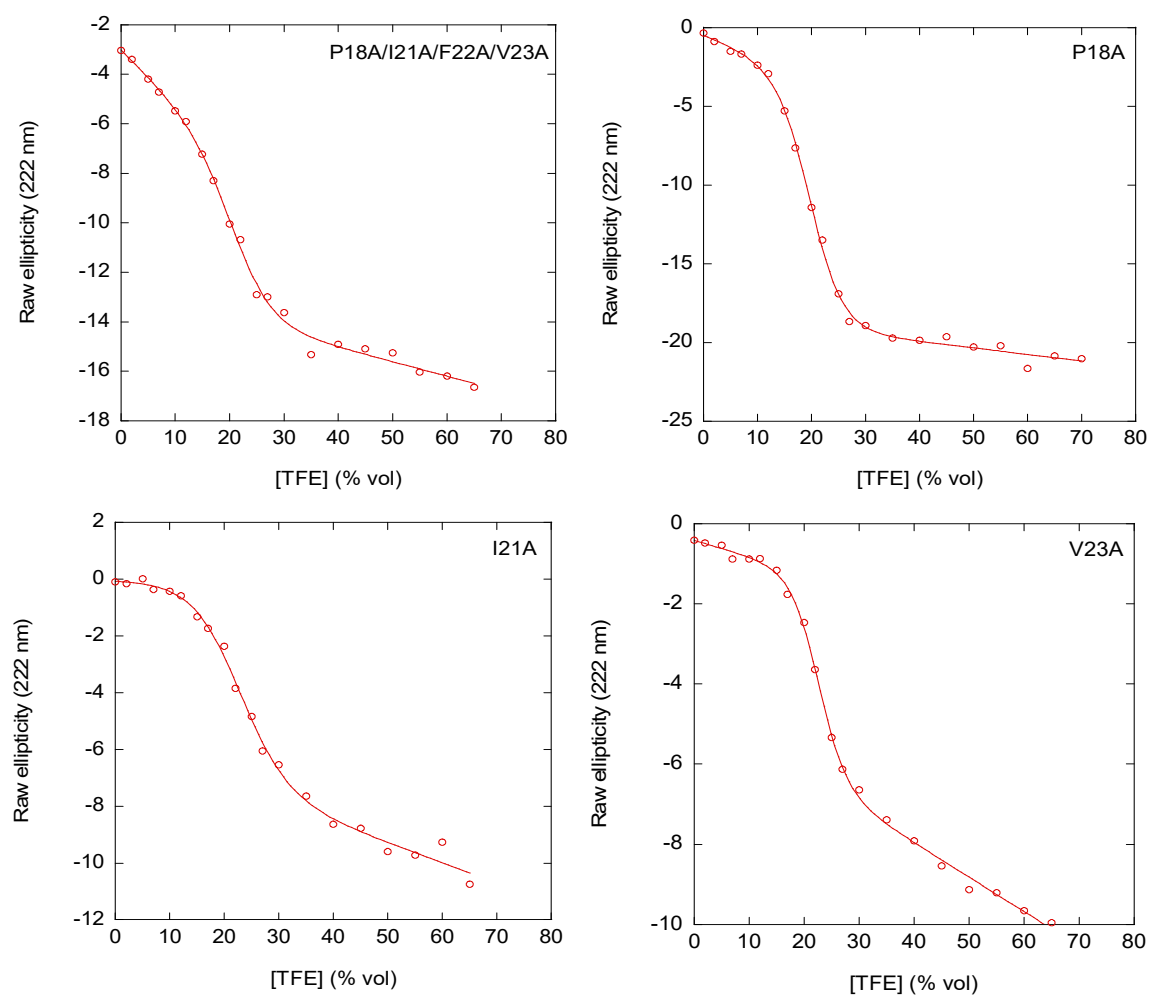

Figure 1. TFE titrations of selected HPr peptides followed by far-UV CD. Sigmoidal change in the $[\Theta]$ at $222 \mathrm{~nm},[\Theta]^{222}$, as the TFE concentration was increased for selected peptides. The line is the fitting to a two-state model $[37,38]$. 
We also carried out MD simulations of the HPr peptides to obtain further insight into their helical propensity. Helical structure is crucial for proteins in general, therefore simulation force fields are parameterized to reproduce it at best, although its occurrence may be overestimated [39]. More importantly, it critically depends on the water model used, especially for disordered protein regions. In spite of such complications, simulations can provide an approximate ranking of the helical tendency for the peptides and, more indirectly, to their ordered/disordered propensity. Table 2 reports the percentage of helical structure calculated for our HPr fragments by using different water models. The most evident finding was that the sole simulation runs with the water model TIP4P-D were capable of predicting a larger amount of helical structures for the triple- and quadruplealanine mutants, in agreement with our findings when reporting only the molar ellipticity; furthermore, the P18A peptide was correctly assessed as the one with the larger helicity among the single-point mutants (in agreement with the findings from the measurements of molar ellipticity at $222 \mathrm{~nm}$; Table 1). The se observations were particularly interesting because the model TIP4P-D was developed to better reproduce the propensity towards disordered protein states over ordered ones [40], thus it normally tends to decrease rather than increase the amount of secondary structure. The refore, the results suggest a tendency towards a very disordered (and likely context-dependent) structure of the HPr peptides, and especially those with multiple alanine mutations. It is also worth noting that, in all cases, the region involving helical fold was the one expected in the structure of the intact, wild-type HPr (residues Ala16-Thr27).

Table 2. Helical populations of $\operatorname{HPr}^{9-30}$ peptides as measured by MD simulations with different water models.

\begin{tabular}{crcc}
\hline Peptide & TIP3P & TIP4P & TIP4P-D $^{\mathbf{c}}$ \\
\hline Wild-type & $18 \%$ & $21 \%$ & $15 \%$ \\
P18A & $12 \%$ & $18 \%$ & $34 \%$ \\
I21A & $25 \%$ & $34 \%$ & $20 \%$ \\
F22A & $34 \%$ & $29 \%$ & $20 \%$ \\
V23A & $20 \%$ & $23 \%$ & $21 \%$ \\
P18A/I21A/V23A & $33 \%$ & $17 \%$ & $36 \%$ \\
P18A/I21A/F22A/V23A & $14 \%$ & $14 \%$ & $38 \%$ \\
\hline
\end{tabular}

a $[41] ;{ }^{\mathrm{b}}[41] ;{ }^{\mathrm{c}}[40]$.

To sum up, from far-UV CD experiments and MD simulations, it could be concluded that the peptides were mainly disordered in aqueous solution, and the mutations did not seem to substantially increase the amount of helical structures, when compared to the wild-type one, although they were designed to increase such population by introducing additional alanine residues. The values of the residual helicity in the peptides varied among the far-UV CD approaches used, as well as in the comparison between the in silico and experimental methods. The $\mathrm{n}$, it could be deduced that the residual helical structure was highly flexible.

To further confirm the inherently disordered nature of the HPr peptides, we carried out homonuclear $2 \mathrm{D}-{ }^{1} \mathrm{H}-\mathrm{NMR}$ experiments. We observed that the peptides were mainly disordered in aqueous solution, as shown by the absence of long- or medium-range NOEs along the chain (Figure 2); some sequential $\mathrm{NN}(i, i+1) \mathrm{NOEs}$ (and ROEs) were observed for particular residues of the mutants, around the site where the mutation was introduced. Assignments of the triple and quadruple mutants in aqueous solution or $40 \%$ TFE (see below) were especially difficult due to the overlapping of several alanine resonances.

We also carried out NMR experiments in the presence of $40 \%$ TFE, when the titration of all peptides had reached a plateau (Figure 1). We conducted these experiments to ensure that all the peptides had a similar tendency to adopt a helix-like conformation for the same residues. Both the NOE pattern (presence of $\mathrm{NN}(i, i+1), \mathrm{NN}(i, i+2), \mathrm{NN}(i, i+3), \alpha \mathrm{N}(i$, $i+3), \alpha \mathrm{N}(i, i+4)$, and $\alpha \beta(i, i+3)$ contacts) (Figure S3) and the upfield shift of the $\mathrm{H}_{\alpha}$ 
protons indicated the presence of helixlike conformations between Ala16 and Thr26 (see Supplementary tables); these residues were also part of the first $\alpha$-helix in the intact $\mathrm{HPr}$. The $n$, there was an intrinsic tendency in that region to acquire a helix-like structure, even when mutations were made.

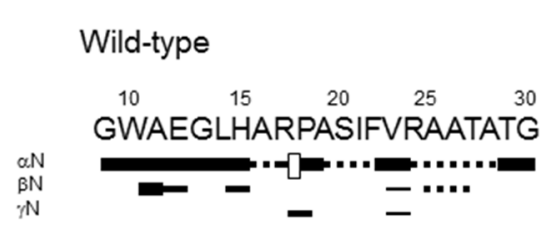

$121 \mathrm{~A}$
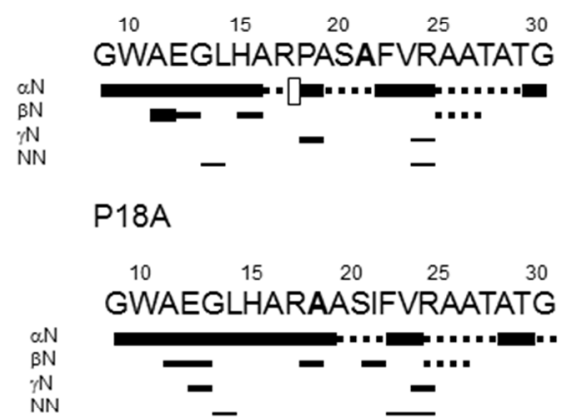

$\mathrm{P} 18 \mathrm{~A} / \mathrm{I} 21 \mathrm{~A} / \mathrm{V} 23 \mathrm{~A}$

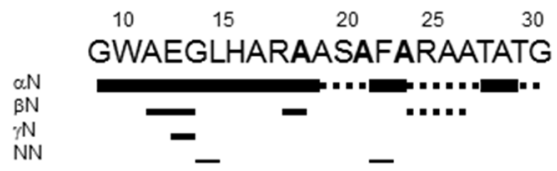

V23A

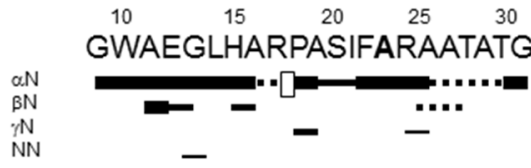

$\mathrm{P} 18 \mathrm{~A} / \mathrm{I} 21 \mathrm{~A} / \mathrm{F} 22 \mathrm{~A} / \mathrm{N} 23 \mathrm{~A}$

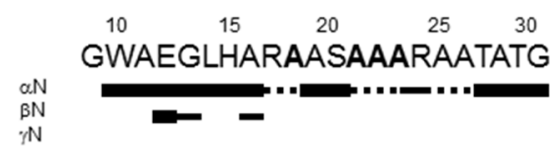

F22A

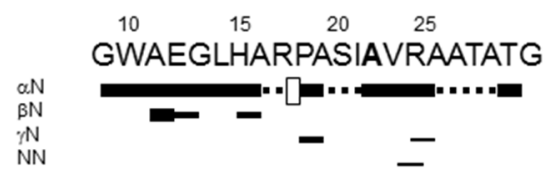

Figure 2. Conformational characterization of the HPr peptides by NMR. An NOE diagram of isolated HPr peptides in aqueous solution. NOEs were classified into strong, medium, or weak, as represented by the height of the bar underneath the sequence; signal intensity was judged by visual inspection from the NOESY experiments. The dotted lines indicate NOE contacts that could not be unambiguously assigned. The blank squares correspond to the sequential $\alpha \delta(i, i+1) \mathrm{NOE}$ observed between a residue preceding a proline and the proline itself.

We also determined whether the peptides in aqueous solution were monomeric or had a tendency to oligomerize, and to that end, we conducted diffusion-ordered spectroscopy (DOSY) experiments (Table 3). All the peptides showed a translational diffusion coefficient, $D$, in agreement with the value expected for a hydrodynamic radius, $R_{\mathrm{h}}$, of a monomeric polypeptide chain of the corresponding molecular weight. The refore, the peptides were monomeric in aqueous solution under our experimental conditions. It is interesting to note that for the wild-type peptide, we previously determined $D$ at infinite dilution [30], and the value obtained $\left(1.4 \pm 0.4 \mathrm{~cm}^{2} \mathrm{~s}^{-1}\right)$ agreed with that measured in this work by using dioxane as reference.

Table 3. The sequence of the $\operatorname{HPr}^{9-30}$ peptides.

\begin{tabular}{|c|c|c|c|}
\hline Peptide $^{a}$ & MW (Da) & $D\left(\mathrm{~cm}^{2} \mathrm{~s}^{-1}\right) \times 10^{6}\left(R_{\mathrm{h}}, \AA\right)^{\mathrm{b}}$ & $R_{\mathrm{h}}(\AA)^{\mathrm{c}}$ \\
\hline Wild-type & 2280.59 & $1.95 \pm 0.03(11 \pm 1)$ & 12.9 \\
\hline P18A & 2254.51 & $2.0 \pm 0.1(11 \pm 1)$ & 12.8 \\
\hline F22A & 2204.50 & $1.83 \pm 0.03(11 \pm 1)$ & 12.6 \\
\hline $\mathrm{I} 21 \mathrm{~A}$ & 2238.51 & $1.9 \pm 0.1(11 \pm 1)$ & 12.7 \\
\hline $\mathrm{V} 23 \mathrm{~A}$ & 2252.54 & $2.0 \pm 0.1(11 \pm 1)$ & 12.8 \\
\hline $\mathrm{P} 18 \mathrm{~A} / \mathrm{I} 21 \mathrm{~A} / \mathrm{V} 23 \mathrm{~A}$ & 2184.42 & $2.5 \pm 0.4(9 \pm 2)$ & 12.6 \\
\hline $\mathrm{P} 18 \mathrm{~A} / \mathrm{I} 21 \mathrm{~A} / \mathrm{F} 22 \mathrm{~A} / \mathrm{V} 23 \mathrm{~A}$ & 2108.32 & $1.7 \pm 0.1(12 \pm 2)$ & 12.4 \\
\hline
\end{tabular}

${ }^{a}$ Mutated residues are in bold. ${ }^{\mathrm{b}}$ Uncertainties are fitting errors to the exponential curve of $I / I_{0}$ versus $\mathrm{G}^{2}$. The $R_{\mathrm{h}}$ values of the peptides (within the parentheses) were obtained from comparison with the $R_{\mathrm{h}}$ of dioxane $(2.12 \AA)$ [42]. ${ }^{\mathrm{c}}$ Calculated from the scale law: $R_{\mathrm{h}}=(0.027 \pm 0.01) \mathrm{MW}(0.50 \pm 0.01)$ [43]. 


\subsection{Binding of the HPr Peptides to EIN $N^{s c}$ and Rsdec}

By following a two-part approach, we tested whether the peptides were capable of binding to any of the two proteins that intact $\mathrm{HPr}^{\mathrm{sc}}$ binds $[25,29,31]$, and whether the binding affinity was modified by the introduced mutations. First, we used steadystate fluorescence and far-UV CD to determine whether there were some spectroscopic changes in the signal of the proteins and/or the peptides upon binding. Second, we used fluorescence spectroscopy and ITC to determine the affinity constant in the association between the peptides and each of the proteins.

A comparison of the far-UV CD spectra of the complexes with the addition ones, obtained by the sum of the spectra of the corresponding isolated polypeptides (Figure 3), indicated that the variations between the spectra were not very large for both $\mathrm{Rsd}^{\mathrm{ec}}$ and EIN ${ }^{\text {sc }}$. The se findings indicated that the binding did not alter the structural properties of the protein or the peptides (Figure 3) or, alternatively, that the binding was spectroscopically silent from the point of view of monitoring it by using far-UV CD spectroscopy. The changes in the fluorescence spectra were not very large either; nevertheless, small changes were observed, and these variations could be useful in determining the affinity by fluorescence titrations (see below). The refore, from the fluorescence measurements, it was evident that the binding took place, and that the environment around the sole tryptophan of the peptides changed in the presence of the other proteins.
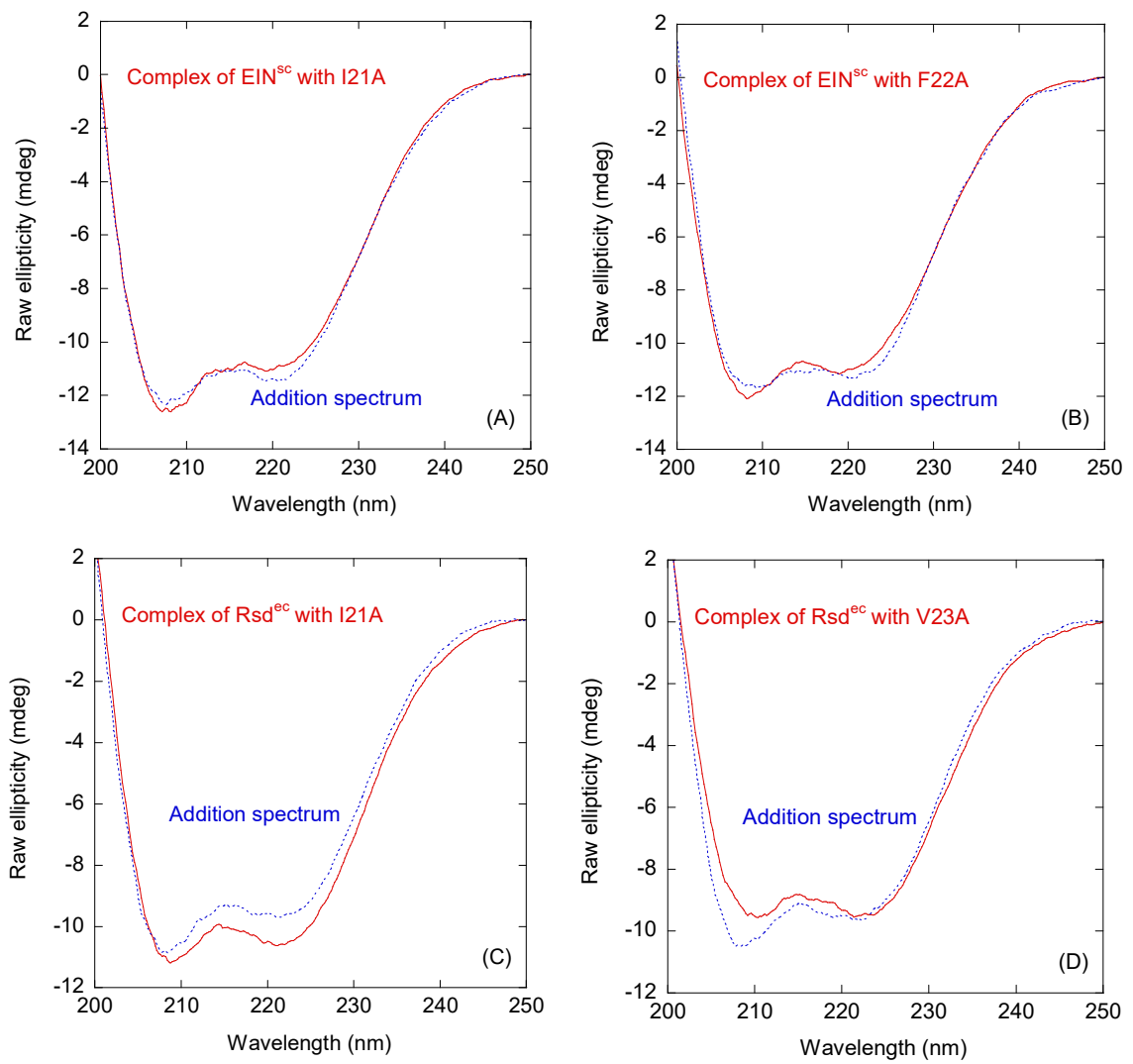

Figure 3. Binding between two selected HPr peptides and $\mathrm{EIN}^{\mathrm{sc}}$ and $\mathrm{Rsd}^{\mathrm{ec}}$, as monitored by spectroscopic techniques. (A) Far-UV CD spectrum of the complex EIN ${ }^{\mathrm{sc}} / \mathrm{I} 21 \mathrm{~A}$ and the one obtained by the addition of the spectra of the two isolated polypeptide chains. (B) Far-UV CD spectrum of the complex EIN ${ }^{\text {sc }} / \mathrm{F} 22 \mathrm{~A}$ and that obtained by the addition of the spectra of the two isolated polypeptide chains. (C) Far-UV CD spectrum of the complex $\mathrm{Rsd}^{\mathrm{ec}} / \mathrm{I} 21 \mathrm{~A}$ and that obtained by the addition of the spectra of the two isolated polypeptide chains. (D) Far-UV CD spectrum of the complex $\mathrm{Rsd}^{\mathrm{ec}} / \mathrm{V} 23 \mathrm{~A}$ and the one obtained by the addition of the spectra of the two isolated polypeptide chains. The experiments were carried out at $25^{\circ} \mathrm{C}$ in $50 \mathrm{mM}$ Tris buffer ( $\mathrm{pH} 7.0$ ). 
To quantify the extent of such binding, we carried out fluorescence titrations and ITC measurements. In the case of EIN ${ }^{\mathrm{sc}}$, we could not obtain a measurable value for most of the mutants, either by ITC or fluorescence (Table 4, Figure 4 and Figure S4). The refore, it seemed that the mutations of P18A, I21A, F22A or V23A essentially hampered the binding to EIN ${ }^{\mathrm{sc}}$. In addition, there was not a direct relationship between the number of mutations made and the changes in the affinity; for instance, the affinity of the quadruple mutant for EIN ${ }^{\text {sc }}$ was two-fold that of the wild-type peptide. In the few cases that could be measured for EIN ${ }^{\mathrm{sc}}$, the mutant with the lowest affinity (i.e., larger $K_{\mathrm{d}}$ ) was V23A. On the other hand, for $\mathrm{Rsd}^{\mathrm{ec}}$, we were able to determine the affinity of all the peptides by ITC (although we could not do so by using fluorescence). We observed that any mutation increased the dissociation constant, and then decreased the affinity. The refore, a larger number of mutations does not imply a larger $K_{\mathrm{d}}$, and there must be compensatory effects (structural versus interaction effects) in the mutations. Finally, it is important to indicate that, although the absolute values of the dissociation constants obtained from fluorescence and calorimetric were not exactly the same, the changes induced by the mutations in the HPr-peptides were similar.

Table 4. Affinities of the peptides for EIN ${ }^{s c}$ and Rsd ${ }^{\text {ec }}$ as measured by ITC and fluorescence.

\begin{tabular}{|c|c|c|c|c|}
\hline \multirow{2}{*}{ Peptide $^{a}$} & \multicolumn{2}{|c|}{$\mathrm{EIN}^{\mathrm{sc}}$} & \multicolumn{2}{|c|}{ Rsd $^{\text {ec }}$} \\
\hline & $K_{\mathrm{d}}{ }^{\mathrm{a}}(\mu \mathrm{M})$ & $\Delta H(\mathrm{kcal} / \mathrm{mol})$ & $K_{\mathrm{d}}{ }^{\mathrm{a}}(\mu \mathrm{M})$ & $\Delta H(\mathrm{kcal} / \mathrm{mol})$ \\
\hline Wild-type & $2.3 \pm 0.4(10 \pm 7)$ & $-0.8 \pm 0.4$ & $1.4 \pm 0.3(5 \pm 2)$ & $1.3 \pm 0.4$ \\
\hline P18A $b, c$ & $(-)$ & $(-)$ & $2.2 \pm 0.4(-)$ & $1.1 \pm 0.4$ \\
\hline $\mathrm{I} 21 \mathrm{~A}$ & $(-)$ & $(-)$ & $2.6 \pm 0.4(8 \pm 1)$ & $1.0 \pm 0.4$ \\
\hline$F 22 A^{b}$ & $(-)$ & $(-)$ & $5.9 \pm 0.7(11 \pm 6)$ & $1.1 \pm 0.5$ \\
\hline $\mathrm{V} 23 \mathrm{~A}^{\mathrm{c}}$ & $9.1 \pm 0.9(9 \pm 4)$ & $-6.6 \pm 0.5$ & $8.3 \pm 0.9(-)$ & $-0.8 \pm 0.5$ \\
\hline $\mathrm{P} 18 \mathrm{~A} / \mathrm{I} 21 \mathrm{~A} / \mathrm{V} 23 \mathrm{~A} \mathrm{~b}^{\mathrm{b}, \mathrm{c}}$ & $(-)$ & $(-)$ & $2.6 \pm 0.4(-)$ & $0.6 \pm 0.4$ \\
\hline $\mathrm{P} 18 \mathrm{~A} / \mathrm{I} 21 \mathrm{~A} / \mathrm{F} 22 \mathrm{~A} / \mathrm{V} 23 \mathrm{~A}$ & $1.1 \pm 0.2(11 \pm 6)$ & $0.2 \pm 0.4$ & $5.0 \pm 0.7(10 \pm 4)$ & $4.3 \pm 0.5$ \\
\hline
\end{tabular}

a The values within the parentheses for the corresponding protein were obtained from fluorescence titration measurements. Uncertainties indicated for the fluorescence values are fitting errors. ${ }^{b}$ It was not possible to fit the fluorescence titration curve between the corresponding peptide and EIN ${ }^{\text {sc }}$. ${ }^{\mathrm{c}}$ It was not possible to fit the fluorescence titration curve between the corresponding peptide and Rsd ${ }^{\text {ec }}$.

Interpretation of the enthalpic and entropic contributions for the binding of the different peptides was questionable. Experiments were performed in Tris, a buffer with a large ionization enthalpy (ca. $+11 \mathrm{kcal} / \mathrm{mol}$ ), and even for a small net number of protons exchanged upon complex formation, the contribution of the buffer to the observed enthalpy (and entropy) was non-negligible. In addition, different peptides might exchange a different net number of protons, making comparisons difficult and unsound. Even if nonionizable residues were mutated to alanine, those substitutions might alter the ionization properties of ionizable side-chains and the alterations exerted upon complex formation. However, that was not a problem for the affinity, and dissociation constants were reliable, because the buffer did not affect the binding affinity as long as the $\mathrm{p} K_{\mathrm{a}}$ of the buffer was close to the experimental $\mathrm{pH}$, and could be compared, which was the purpose of using ITC for studying these interactions. 

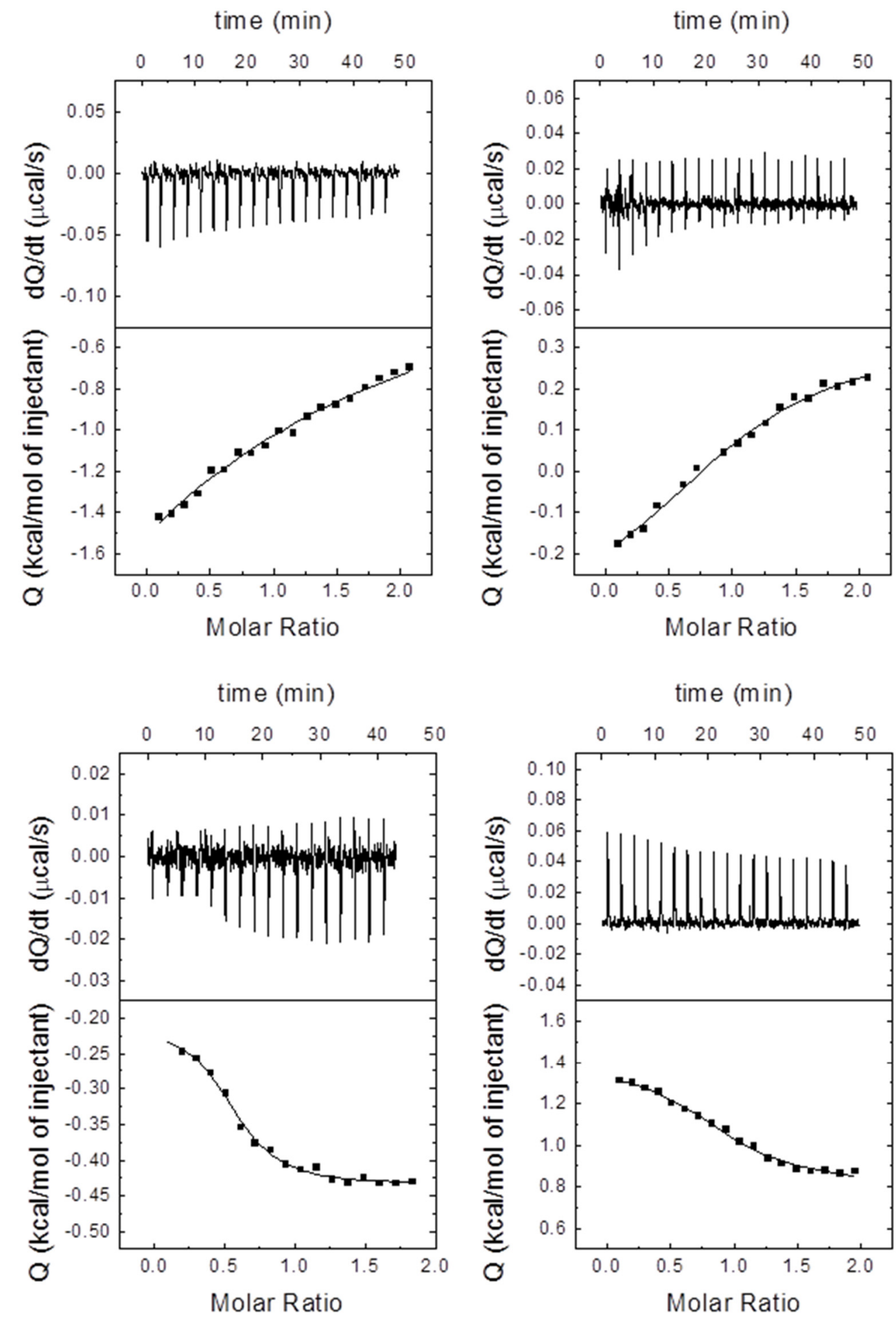

Figure 4. Binding between two selected HPr peptides and EIN ${ }^{s c}$ and Rsd ${ }^{\text {ec }}$, as monitored by ITC. Interaction of V32A with EIN ${ }^{\text {sc }}$ (top left) and Rsd ${ }^{\text {ec }}$ (top right), and P18A/I21A/F22A/V23A with EIN ${ }^{\text {sc }}$ (bottom left) and Rsd ${ }^{\text {ec }}$ (bottom right). The upper plots show the thermogram (thermal power required to maintain a minimal temperature difference between sample and reference cells as a function of time), and the lower plots show the binding isotherm (titrant-normalized heat effects per injection as a function of the molar ratio, the quotient between the titrant and titrand concentrations in the sample cell). The continuous lines are the fitting curves to a single binding-site model. The experiments were carried out at $25^{\circ} \mathrm{C}$ in $50 \mathrm{mM}$ Tris buffer (pH 7.0). 


\subsection{The Fragments Displayed Antibacterial Activity against Staphylococcus aureus}

To ascertain whether the mutated positions within the HPr peptides also had an effect on the capacity to inhibit the growth of $S$. aureus, their minimal inhibitory concentrations (MICs) were determined by the two-fold broth microdilution method (Table 5). Thus, it was revealed that I21A, V23A, and P18A/I21A/F22A/V23A could not inhibit the bacteria growth even at the highest peptide concentration tested $(400 \mu \mathrm{M})$. Among the peptides showing at least a minimum antibacterial activity, F22A was the least potent one, showing an MIC of $400 \mu \mathrm{M}$. The peptides endowed with the highest antibacterial activity were, in ascending order, wild-type, P18A/I21A/V23A, and P18A, with MICs of 40, 60, and $120 \mu \mathrm{M}$, respectively. Thus, it seemed that the mutation F22A had a huge effect on MIC (either in the isolated mutation or in the quadruple mutant), and the triple mutant most likely had a low MIC because Phe22 was not mutated. Phe22 is a key residue to attain a good antibacterial effect.

Table 5. Antibacterial activity of the different HPr peptides against S. aureus ${ }^{\text {a }}$.

\begin{tabular}{cc}
\hline Peptides & MIC $(\boldsymbol{\mu M})$ \\
\hline Wild-type & 40 \\
P18A & 120 \\
I21A & $>400$ \\
F22A & 400 \\
V23A & $>400$ \\
P18A/I21A/V23A & 60 \\
P18A/I21A/F22A/V23A & $>400$ \\
\hline
\end{tabular}

a All experiments were performed in triplicate $(\mathrm{sd}=0)$.

\section{Discussion}

The dissociation constant of the interaction between Rsd and HPr in E. coli reported as $8.87 \mathrm{nM}$ [22], as measured by surface plasmon resonance (SPR). Our measurements, by using fluorescence and biolayer interferometry (BLI) for the intact $\mathrm{HPr}^{\mathrm{sc}}$ [24], suggested that the binding occurred in the low micromolar range $(0.2$ to $1.5 \mu \mathrm{M}$, depending on the technique), in agreement with previous measurements [22,23]. We previously showed that the peptide comprising residues Gly9-Ala30 of $\mathrm{HPr}^{\mathrm{sc}}$ also binds to Rsd ${ }^{\mathrm{ec}}$ with an affinity similar to that of the intact protein [24]. In this work, we showed that mutations of residues Pro18, Ile21, Phe22, and Val23 into alanine in such peptide led to a decreased affinity for $\mathrm{Rsd}^{\mathrm{ec}}$, but such decrease did not seem to have a clear direct relationship with the number of mutations, or with the position where they were located. The changes were more drastic in the case of EIN ${ }^{\mathrm{sc}}$, because we could measure an affinity constant only for a few peptides. The se results seemed to suggest that the first helix of HPr was optimized for binding with EIN ${ }^{\mathrm{sc}}$ rather than with Rsd ${ }^{\mathrm{ec}}$. All residues considered were involved in attaining the more favourable binding (i.e., the lowest dissociation constant), and an increase in helicity yields to a lower $K_{\mathrm{d}}$. That is, in broad terms, residual helicity played a role in defining binding affinity. The se findings suggested that disorder and residual helicity of $\mathrm{HPr}^{\mathrm{sc}}$ at its first helical region had a key role in determining the balance between binding affinities and binding specificities in the PTS system. In principle, increasing helical content could be considered beneficial for the interaction, because: (1) the HPr region interacting with $\mathrm{EI}^{\mathrm{sc}}$ or Rsd ${ }^{\mathrm{ec}}$ adopted an $\alpha$-helical conformation; (2) the wild-type HPr peptide was disordered in solution; and (3) the binding resulted in the formation of an $\alpha$-helix in the peptide. However, the mutations introduced could affect the intramolecular interactions, and thus increase the dissociation constant for the mutant peptides. In addition, the $\alpha$ helix propensity of that region might be not optimal in wild-type HPr (although optimal for interacting with a preferred target, e.g., EI), but the region still adopted an $\alpha$-helical conformation within full-length HPr because of the structural constraints and the network of cooperative intramolecular interactions, absent in the isolated HPr peptide. 
It could be argued that we did not find any direct evidence that the peptides did not acquire a helical structure upon binding [14]; however, since the region encompassing the peptides was folded in the complexes between the intact proteins, it does not seem unreasonable to assume that there was a folding-upon-binding event when the peptides and EIN and Rsd were used. In addition, we recently obtained a fragment comprising the first 48 residues of HPr, and we observed that, upon binding to EIN and Rsd, the residues that showed the largest variations in chemical shifts or broadenings were those around His15 and Arg17 [44], suggesting that the conformation around this region changed in the interaction with such large proteins.

It is important to indicate that the small-scale alanine scanning carried out in this work with the peptides consisted of removing residues (such as Phe22 and Val23) that did not have a large number of interactions with EIN or Rsd, and therefore in addition to attempting to increase helicity, we could also be removing van der Waals interactions and side-chain-side-chain contacts with nearby residues of the peptide. In fact, according to the structure of the complex between EIN and HPr from E. coli (PDB entry 3EZE) the residues of HPr that have a larger number of contacts with EIN are Thr16, Arg17, and Ala20 (or Ala16, Arg17, and Ser20 in S. coelicolor; Figure 2) [14], and in the residues mutated in the peptide, only Ph22 and Val23 showed hydrophobic contacts with an $\alpha$-helix in EIN (PDB entry: 3EZE) [14]. Furthermore, in the case of Pro18 to alanine, the mutation could affect the helix-capping, and it could potentially change the entropy of binding. However, keeping in mind those limitations of our approach, alanine scanning (with a wider range of mutations than those used in this work) has been used to study the relationship between residual helicity in a protein and the binding to other partners (either in homo-dimerization or hetero-dimerization experiments) $[45,46]$.

Along these lines, as observed in the antibacterial assays performed, the peptides that showed the lowest dissociation constants here (i.e., 1.4, 2.2, and $2.6 \mu \mathrm{M}$ for wild-type, P18A, and P18A/I21A/V23A, respectively) (Table 4) were also those that achieved the lowest MICs (i.e., 40, 60, and $120 \mu \mathrm{M}$ for wild-type, P18A/I21A/V23A, and P18A, respectively) (Table 5). The refore, roughly, the higher the binding affinity of the HPr peptides for $\mathrm{Rsd}^{\mathrm{ec}}$, the higher the inhibition of the bacterial growth, although it should be considered that some other factors might be hampering the activity of the peptides in biological systems, such as their penetration ability into bacteria. It should also be noted that the designed peptides presented antibacterial activity against a species of bacteria (S. aureus) different from those initially used for peptide design (Streptomyces coelicolor). Although the MICs obtained were too high to suggest their use as antibacterial in their current form, the observed inhibitory effect demonstrated the circumvention of the defences of Grampositive bacteria against antibiotics. Thus, the biophysical aspects of our investigation have direct consequences for possible biotechnological applications, since bacterial pathogens are becoming increasingly resistant to the antibiotics used to tackle infectious diseases. More than 150 antibiotics belonging to at least 17 different classes are now available, and each class operates at a specific site within the cell. However, the increasing occurrence of antibiotic resistance makes it more compelling than ever to pursue the search for new pharmacological targets [47], such as the peptides explored in this work.

\section{Materials and Methods}

\subsection{Materials}

Ampicillin, isopropyl- $\beta$-D-1-thiogalactopyranoside, deuterium oxide, and deuterated TFE were obtained from Apollo Scientific (Stockport, UK). Imidazole, Trizma base, SIGMAFAST protease tablets, sodium trimethylsilyl $\left[2,2,3,3-{ }^{2} \mathrm{H}_{4}\right]$ propionate (TSP), and 2,2,2trifluoethanol were purchased from Sigma-Aldrich (Madrid, Spain). Both the Luria-Bertani (LB) and Mueller-Hinton (MH) bacterial culture broths were also from Sigma-Aldrich. Amicon centrifugal devices with a cut-off molecular weight of 3.5 or $10 \mathrm{kDa}$ were from Millipore (Barcelona, Spain). Dialysis tubing with a cut-off molecular weight of $3.5 \mathrm{kDa}$ was from Spectrapore (VWR, Barcelona, Spain). Standard suppliers were used for all 
other chemicals. Water was deionized and purified on a Millipore system. The rest of the materials used were of analytical grade.

\subsection{Peptides}

Peptides were amidated at their C-termini and acetylated at the N-termini. The $y$ were obtained from NZYTech (Lisbon, Portugal) with purity higher than $95 \%$ as tested by mass spectra. Peptide concentrations were determined from the absorbance of individual amino acids at $280 \mathrm{~nm}$ [48]. In addition to the wild-type sequence $\mathrm{HPr}^{9-30}$, the single mutants P18A, I21A, F22A, and V23A were studied, together with the triple-mutant $\mathrm{P} 18 \mathrm{~A} / \mathrm{I} 21 \mathrm{~A} / \mathrm{V} 23 \mathrm{~A}$ and the quadruple-mutant P18A/I21A/F22A/V23A. It is important to emphasize that the residues of HPr in all the chosen positions did not show a large number of contacts with the EIN interface [14], and the fact that they showed a larger $K_{d}$ than the wild-type (Table 4) suggested that binding was not only affected by residues involved directly in the interface. Only residues Ph22 and Val23 showed hydrophobic contacts with an $\alpha$-helix in EIN (PDB entry: 3EZE) [14].

We preferred using the isolated mutant peptides to study the effect of helicity on binding, instead of the entire mutated HPr, since we showed previously that the isolated wild-type peptide of HPr (Table 3) had a similar affinity for EIN and Rsd to that of the intact HPr for the same proteins $[24,28,31]$. By using the designed peptides (Table 1), we avoided any other possible interactions that could have the mutated residues with the rest of HPr.

\subsection{Protein Expression and Purification}

The wild-type Rsd vector, containing the Rsd ${ }^{\mathrm{ec}}$ with a His-tag, was a kind gift from Ann Hochschild (Harvard, MA, USA). The protein was expressed in the C41 E. coli strain [49], and the cells were grown in LB broth. The protein was purified as described $[24,50]$. EIN ${ }^{s c}$ was also expressed and purified as described $[10,29,31]$. Protein concentrations were determined in all cases from absorbance, and by employing the extinction coefficient at $280 \mathrm{~nm}$ calculated from their sequence [48].

\subsection{Fluorescence}

Regarding the presence of amino acid residues yielding a fluorescence signal, $\mathrm{Rsd}^{\mathrm{ec}}$ had two Trp and eight Tyr residues, and EIN ${ }^{s c}$ had four Tyr residues, whereas the peptides only contained Trp10 (Table 3). Spectra were collected at $25^{\circ} \mathrm{C}$ on a Cary spectrofluorometer (Agilent, Madrid, Spain), with a Peltier temperature controller. The samples were prepared the day before and left overnight at $5^{\circ} \mathrm{C}$. Before measurements, the samples were incubated for $1 \mathrm{~h}$ at $25^{\circ} \mathrm{C}$. A quartz cell with a $1 \mathrm{~cm}$ path length (Hellma, Kruibeke, Belgium) was used. In all the experiments, the slit widths were equal to $5 \mathrm{~nm}$ for both the excitation and emission lights. Protein samples were excited at either 280 or $295 \mathrm{~nm}$. The experiments were performed between 300 and $400 \mathrm{~nm}$. The signal was acquired for $1 \mathrm{~s}$, and the increment of wavelength was set to $1 \mathrm{~nm}$. Appropriate blank corrections were made in all spectra. For the binding experiments, $3 \mu \mathrm{M}$ of either protein $\left(\mathrm{Rsd}^{\mathrm{ec}}\right.$ or EIN $\left.{ }^{\mathrm{sc}}\right)$ and $15 \mu \mathrm{M}$ of the corresponding peptide were mixed. The experiments in aqueous solution were acquired in Tris buffer ( $50 \mathrm{mM}, \mathrm{pH} 7.0)$.

For the titration between either of the two proteins $\left(\mathrm{Rsd}^{\mathrm{ec}}\right.$ or EIN $\left.{ }^{\mathrm{sc}}\right)$ and the corresponding peptide, increasing amounts of the latter, in a concentration range of 0 to $30 \mu \mathrm{M}$, were added to a solution with a fixed concentration of each protein $(3 \mu \mathrm{M})$. The experimental set-up was identical to that described above, including preparation of the samples the day before and their storage overnight at $5{ }^{\circ} \mathrm{C}$. Before measurements, the samples were incubated for $1 \mathrm{~h}$ at $25^{\circ} \mathrm{C}$. The fluorescence of a blank solution containing only the corresponding peptide was subtracted for each data point. The dissociation constant of the complex, $K_{\mathrm{d}}$, was calculated by fitting the plot of the observed fluorescence variation to [51,52]:

$$
F=F_{0}+\frac{\Delta F_{\max }}{2[\text { Rsd } / E]_{\mathrm{T}}}\left[\left([\text { Peptide }]_{\mathrm{T}}+[\text { Rsd } / \mathrm{EIN}]_{\mathrm{T}}+K_{d}\right)-\left(\left([\text { Peptide }]_{\mathrm{T}}+[\text { Rsd } / \mathrm{EIN}]_{\mathrm{T}}+K_{d}\right)^{2}-4[\text { Peptide }]_{\mathrm{T}}[\text { Rsd } / \mathrm{EIN}]_{\mathrm{T}}\right)^{1 / 2}\right]
$$


where $F$ is the measured fluorescence at any particular concentration of the corresponding peptide after subtraction of the blank; $\Delta F_{\max }$ is the maximal change in the fluorescence of each protein when all of the corresponding peptide was forming the complex, compared to the fluorescence of each isolated protein; $F_{0}$ is the fluorescence intensity when no other protein was added; [Rsd $/ \mathrm{EIN}]_{\mathrm{T}}$ is the constant, total concentration of each protein $(3 \mu \mathrm{M})$; and [Peptide $]_{\mathrm{T}}$ is that of the corresponding peptide, which was varied during the titration. The $K_{\mathrm{d}}$ was determined by following the fluorescence at selected wavelengths and fitting experimental data to Equation (1). Titration of the peptides with each protein was repeated three times, and in all cases, the variations among the different repetitions were less than $5 \%$. At all used concentrations, the fluorescence was corrected by the inner-filter effects [53].

\subsection{Circular Dichroism}

Spectra were collected on a Jasco J810 spectropolarimeter (Jasco, Tokyo, Japan) interfaced with a Peltier unit. Far-UV measurements were performed with samples placed in quartz cells with a $0.1 \mathrm{~cm}$ path length (Hellma, Kruibeke, Belgium), with a response time of $2 \mathrm{~s}$, a band width of $1 \mathrm{~nm}$, and a scan velocity of $50 \mathrm{~nm} / \mathrm{min}$. For all peptides, a wide range of concentrations $(10-50 \mu \mathrm{M})$ was used to determine whether either the shape or the intensity of the spectra was concentration-dependent. None of those features changed in the concentration range explored. The experiments in aqueous solution were acquired at $5{ }^{\circ} \mathrm{C}$ in Tris buffer $(50 \mathrm{mM}, \mathrm{pH} 7.0)$. Raw ellipticity was converted to molar ellipticity, $[\Theta]$, from which the fraction of helical populations was determined as previously described [54]. For the experiments in the presence of each protein (repeated three times), the same concentration used in the fluorescence experiments was used, and the experimental set-up was the same as described above for the isolated peptides.

For experiments in the presence of TFE, the same set of experimental parameters was used. Cosolvent concentrations were indicated in percentage of volume (\%). The helical population for each soluble peptide in aqueous solution was determined assuming a twostate equilibrium for the helical $\leftrightarrow$ random-coil transition (as suggested by the presence of an isodichroic wavelength in the titrations of all peptides examined) [37,38]. The peptide concentration for these experiments was $20 \mu \mathrm{M}$.

\subsection{NMR Spectroscopy}

The NMR experiments were performed at $10{ }^{\circ} \mathrm{C}$ with a Bruker Avance II $500 \mathrm{spec}-$ trometer (Bruker $\mathrm{GmbH}$, Karlsruhe, Germany) equipped with a triple resonance probe and z-pulse field gradients. The temperature of the probe was calibrated with methanol [55]. All experiments were carried out at pH 7.2 with $50 \mathrm{mM}$ Tris buffer (not corrected for isotope effects) in $\mathrm{H}_{2} \mathrm{O} / \mathrm{D}_{2} \mathrm{O}(90 \% / 10 \%)$, unless otherwise indicated.

(a) $1 \mathrm{D}-{ }^{1} \mathrm{H}-\mathrm{NMR}$ spectra: For peptides, $1 \mathrm{~K}$ scans were acquired with $32 \mathrm{~K}$ acquisition points at concentrations ranging between 70 and $120 \mu \mathrm{M}$. Homonuclear $1 \mathrm{D}-{ }^{1} \mathrm{H}-\mathrm{NMR}$ spectra were processed with TopSpin 2.1 (Bruker GmbH, Karlsruhe, Germany) after zero-filling the spectra. All spectra were referenced to external TSP, considering the $\mathrm{pH}$-dependence of its signals [55].

(b) Translational diffusion NMR (DOSY): Peptide concentrations were the same as those used in the $1 \mathrm{D}-{ }^{1} \mathrm{H}-\mathrm{NMR}$ spectra. Translational self-diffusion measurements were performed with the pulsed-gradient spin-echo sequence in the presence of $100 \% \mathrm{D}_{2} \mathrm{O}$. The following relationship existed between the translational self-diffusion coefficient, $D$, and the delays used during experiment acquisition [54]:

$$
\frac{I}{I_{0}}=-\exp \left(D \gamma_{H}^{2} \delta^{2} G^{2}\left(\Delta-\frac{\delta}{3}-\frac{\tau}{2}\right)\right)
$$

where $I$ is the peak intensity of a particular resonance (or a group of them) at any gradient strength; $I_{0}$ is the maximum peak intensity of the same resonance(s) at the smallest gradient strength (that is, at $2 \%$ of the total power of the gradient coil); $D$ is the translational selfdiffusion constant (in $\mathrm{cm}^{2} \mathrm{~s}^{-1}$ ); $\delta$ is the duration (in s) of the gradient; $G$ is the gradient 
strength (in $\mathrm{T} \mathrm{cm}^{-1}$ ); $\Delta$ is the time (in s) between the gradients; $\gamma_{\mathrm{H}}$ is the gyromagnetic constant of the proton (in rad s ${ }^{-1} \mathrm{~T}^{-1}$ ); and $\tau$ is the recovery delay between the bipolar gradients (100 $\mu$ s in our experiments). The gradient strength $(G)$ was varied in 16 lineal steps, between 2 and $95 \%$ of the total power of the gradient coil of the probe. The gradient strength was calibrated by using the value of $D$ for the residual proton water line in a sample containing $100 \% \mathrm{D}_{2} \mathrm{O}$ placed in a $5 \mathrm{~mm}$ tube [42]. Data were plotted as $I / I_{0}$ versus $G^{2}$, and the exponential factor of the curve was:

$$
D \gamma_{H}^{2} \delta^{2}\left(\Delta-\frac{\delta}{3}-\frac{\tau}{2}\right)
$$

from which $D$ can be obtained. The duration of the gradient $(\delta)$ was $2.25 \mathrm{~ms}$, and the time between the two gradients $(\Delta)$ was set to $200 \mathrm{~ms}$. The signal from the methyl groups between 1.1 and $0.70 \mathrm{ppm}$ were used for integration of the intensity. A final concentration of $1 \%$ of dioxane was added to each peptide; the hydrodynamic radius, $R_{\mathrm{h}}$, of each peptide was obtained for comparison by assuming that the $R_{\mathrm{h}}$ of dioxane was $2.12 \AA$ [42]. The DOSY experiment was repeated twice with fresh samples for each peptide.

(c) $2 \mathrm{D}-{ }^{1} \mathrm{H}-\mathrm{NMR}$ spectroscopy: Two-dimensional experiments were performed with a spectral width of $7801.69 \mathrm{~Hz}$ in each dimension, and in phase-sensitive mode by using the time-proportional phase-incrementation technique (TPPI) [56]; for all peptides, the final concentration in aqueous solution was in the range of 1.5-2 $\mathrm{mM}$. Experiments were also carried out in $40 \%$ deuterated TFE at the same $\mathrm{pH}$ and temperature.

Standard NMR experiments, as well as TOCSY (two mixing times, 60 and $80 \mathrm{~ms}$ ), ROESY (two mixing times, 200 and $300 \mathrm{~ms}$ ), and NOESY experiments (two mixing times, 200 and $300 \mathrm{~ms}$ ) were performed. Data from the TOCSY, ROESY, and NOESY experiments were acquired with a data matrix size of $4 \mathrm{~K}\left(t_{2}\right) \times 512\left(t_{1}\right)$, with the MLEV17 spin-lock sequence [57] in the TOCSY experiments, and $1 \mathrm{~s}$ of relaxation time in all experiments. Typically, 80 scans were acquired per $t_{1}$ increment, and the residual water signal was removed by using the WATERGATE sequence [58]. NOESY and ROESY spectra [59,60] typically were collected with 128 scans per $t_{1}$ increment, with the residual water signal removed by the WATERGATE sequence and a relaxation time of $1 \mathrm{~s}$. Data were zero-filled and resolution-enhanced with phase-shifted sine bell (DQF-COSY) or square sine-bell window functions (TOCSY, NOESY, and ROESY) optimized in each spectrum, baselinecorrected, and processed with the Bruker XWINNMR software. The ${ }^{1} \mathrm{H}$ NMR resonances were assigned using standard sequential assignment processes [61] when possible (see the Results section). The random-coil chemical shift values of $\mathrm{H}_{\alpha}$ protons in aqueous and TFE solutions were obtained from tabulated data for model peptides, and corrected by neighbouring residue effects [62].

\subsection{Isothermal Titration Calorimetry (ITC)}

The experimental set-up and data processing of ITC experiments has been described previously $[29,31,63]$. Rsd ${ }^{\mathrm{ec}}$ or EIN ${ }^{\mathrm{sc}}$ (at 10-20 $\mu \mathrm{M}$ ) were injected into the cell, and the peptides in the syringe $(100-200 \mu \mathrm{M})$ in $50 \mathrm{mM}$ of Tris buffer, $\mathrm{pH}$ 7.0. The temperature for all the experiments was $25^{\circ} \mathrm{C}$. Typically, each calorimetric titration consisted of performing 19 injections with $2 \mu \mathrm{L}$ volume, with a time spacing of $150 \mathrm{~s}$, while stirring at $750 \mathrm{rpm}$ in an Auto-iTC200 high-sensitivity microcalorimeter (MicroCal, Malvern-Panalytical, Malvern, UK). The results were analysed by applying a model that considered a single binding site (assuming a 1:1 stoichiometry) for the peptide/EIN ${ }^{\mathrm{sc}}$ or peptide/Rsd $\mathrm{Se}^{\mathrm{ec}}$ interaction using a nonlinear least-squares regression analysis in Origin 7.0 (OriginLab, Northampton, MA, USA) with user-defined fitting routines.

\subsection{Molecular Dynamics}

We carried out molecular dynamics (MD) simulations to assess the tendency to possess helical structure for each of the peptides, following a protocol previously described [64,65]. The simulations were performed by using the GROMACS package with the Amber 99SB- 
ILDN force field [66]. Three different water models were tested: the traditional three-point model TIP3P; the more accurate four-point model TIP4P [41]; and its variant TIP4P-D [40], which precluded potential overcompaction of disordered protein states. The structures used as starting points of the simulations were built from the corresponding protein fragment in helical conformation as found in the Protein Data Bank (PDB) entry 1RZR [67].

The peptides were modelled with cappings, protonated according to a neutral $\mathrm{pH}$, and solvated in a dodecahedral box with a minimum distance of $1.5 \mathrm{~nm}$ from any edge, and then counterions were added to obtain an overall neutral system. Simulation conditions that included the treatment of Coulombic and van der Waals interactions, use of constraints and time steps in the integration of the equations of motion, and the reference values and coupling times for maintaining constant temperature and pressure, were all as previously described $[68,69]$. Production runs were performed in the isobaric-isothermal ensemble for $50 \mathrm{~ns}$.

\subsection{Antibacterial Assays}

The CECT59 strain of the Gram-positive bacteria Staphylococcus aureus from the Spanish Type Culture Collection (Colección Española de Cultivos Tipo, CECT, Universitat de Valencia, Spain) was used for determining its sensitivity to the HPr peptides studied in this work. The MIC for each peptide was determined by the two-fold broth microdilution method according to the Clinical and Laboratory Standards Institute (CLSI) guidelines [70], with some modifications as previously described [71]. For this testing procedure, a bacteria colony previously grown in $\mathrm{MH}$ agar plates was isolated and incubated in $\mathrm{MH}$ broth at 37 ${ }^{\circ} \mathrm{C}$ overnight to prepare the bacteria inoculum to be used in each assay. The $n$, the bacteria suspensions were adjusted to a $100 \times$ dilution of an $0.5 \mathrm{McF}$ arland turbidity standard in $\mathrm{MH}$ broth and incubated with different concentrations of each peptide in round-bottom 96-well polystyrene plates (Deltalab S.L., Rubí, Spain) $\left(50 \mu \mathrm{L} /\right.$ well) for $24 \mathrm{~h}$ at $37^{\circ} \mathrm{C}$. The peptide concentrations employed comprised two-fold dilutions starting at either 120, 160, or 400 $\mu \mathrm{M}$, depending on the experiment. The MIC was determined as the lowest concentration of peptide that visibly inhibited bacterial growth. All assays were performed in triplicate.

Supplementary Materials: The following are available online at https:/ /www.mdpi.com/article/10 $.3390 /$ ijms221910805/s1.

Author Contributions: Conceptualization, J.L.N., D.O.-A., B.R., A.V.-C., M.P.-S. and A.F.; methodology, J.L.N., D.O.-A., B.R., A.V.-C. and A.F.; validation, J.L.N., D.O.-A., B.R., A.V.-C., M.P.-S. and A.F.; formal analysis, J.L.N., D.O.-A., B.R., A.V.-C., M.P.-S. and A.F.; investigation, J.L.N., D.O.-A., B.R., A.V.-C., M.P.-S. and A.F.; resources, J.L.N., A.V.-C. and A.F.; writing-original draft preparation, J.L.N.; writing-review and editing, J.L.N., D.O.-A., B.R., A.V.-C., M.P.-S. and A.F; project administration, J.L.N., A.V.-C. and A.F.; funding acquisition, J.L.N., A.V.-C. and A.F. All authors have read and agreed to the published version of the manuscript.

Funding: This research was funded by the Spanish Ministry of Economy and Competitiveness and European ERDF Funds (MCIU/AEI/FEDER, EU) (RTI2018-097991-B-I00 to J.L.N., BFU2016-78232-P to A.V.-C., BES-2017-080739 to D.O.-A., and RTI2018-101969-J-I00 to A.F.). The NMR equipment used in this work was funded by Generalitat Valenciana (Spain) and cofinanced with ERDF funds (OP ERDF of Comunitat Valenciana (Spain) 2014-2020).

Institutional Review Board Statement: Not applicable.

Informed Consent Statement: Not applicable.

Data Availability Statement: The data presented in this study are available upon request from the corresponding author.

Acknowledgments: The Rsd ${ }^{\mathrm{ec}}$ was a kind gift from Ann Hochschild (Harvard, MA, USA). We thank Juan Carlos Rodríguez-Díaz (University General Hospital of Alicante, Spain) for his technical support with the antibacterial assays. The European Magnetic Resonance Center (CERM), Sesto Fiorentino (Florence, Italy), is acknowledged for the kind use of its computational resources. We thank the two anonymous reviewers for helpful comments. 
Conflicts of Interest: The authors declare no conflict of interest.

\section{References}

1. Ishihama, A. Adaption of gene expression in stationary phase bacteria. Curr. Opin. Genet. Dev. 1997, 7, 582-589. [CrossRef]

2. Deutscher, J. The mechanisms of catabolite repression in bacteria. Curr. Opin. Microbiol. 2008, 11, 87-93. [CrossRef] [PubMed]

3. Postma, P.W.; Lengeler, J.W.; Jacobson, G.R. Phosphoenolpyruvate: Carbohydrate phosphotransferase systems of bacteria. Microbiol. Rev. 1993, 57, 543-594. [CrossRef] [PubMed]

4. Bruckner, R.; Titgemeyer, F. Carbon catabolite repression in bacteria: Choice of the carbon source and autoregulatory limitation of sugar utilization. FEMS Microbiol. Lett. 2002, 209, 141-148. [CrossRef]

5. Görke, B.; Stülke, J. Carbon catabolite repression in the bacteria. Nat. Microbiol. 2008, 6, 613-624. [CrossRef] [PubMed]

6. Lengeller, J.W.; Jahreis, K. Bacterial PEP-dependent carbohydrate:phosphotransferase systems couple sensing and global control mechanisms. Contrib. Microbiol. 2009, 16, 65-87.

7. Gunnewijk, M.G.; van den Bogaard, P.T.; Veenhoff, L.M.; Heuberger, E.H.; de Vos, W.M.; Kleerebezem, M.; Kuipers, O.P.; Poolman, B. Hierarchical control versus autoregulation of carbohydrate utilization in bacteria. J. Mol. Microbiol. Biotechnol. 2001, 3, 401-413.

8. Galinier, A.; Deutscher, J. Sophisticated regulation of transcriptional factors by the bacterial phosphoenolpyruvate: Sugar phosphotransferase system. J. Mol. Biol. 2017, 429, 773-783. [CrossRef] [PubMed]

9. Lee, B.R.; Lecchi, P.; Panell, L.; Jaffe, H.; Peterkosfsky, A. Identification of the N-terminal domain of enzyme I of the Escherichia coli phosphoenolpyruvate:sugar phosphotransferase system produced by proteolytic digestion. Arch. Biochem. Biophys. 1994, 312, 121-124. [CrossRef]

10. Romero-Beviar, M.; Martínez-Rodríguez, S.; Prieto, J.; Goormaghtigh, E.; Ariz, U.; de Martínez-Chantar, M.L.; Gómez, J.; Neira, J.L. The N-terminal domain of the enzyme I is a monomeric well-folded protein with a low conformational stability and residual structure in the unfolded state. Protein Eng. Des. Sel. 2010, 23, 729-742. [CrossRef]

11. Hurtado-Gómez, E.; Barrera, F.N.; Neira, J.L. Structure and conformational stability of the enzyme I of Streptomyces coelicolor explored by FTIR and circular dichroism. Biophys. Chem. 2005, 115, 229-233. [CrossRef]

12. Hurtado-Gómez, E.; Fernández-Ballester, G.; Nothaft, H.; Gómez, J.; Titgemeyer, F.; Neira, J.L. Biophysical characterization of the enzyme I of the Streptomyces coelicolor phosphoenolpyruvate:sugar phosphotransferase system. Biophys. J. 2006, 90, 4592-4604. [CrossRef] [PubMed]

13. Weigel, M.; Kukuruzinska, M.A.; Nakazawa, A.; Waygood, E.B.; Roseman, S. Sugar transport by the bacterial phosphotransferase system. Phosphoryl transfer reactions catalyzed by enzyme I of Salmonella typhimurium. J. Biol. Chem. 1982, $257,14477-14491$. [CrossRef]

14. Clore, G.M.; Venditti, V. Structure, dynamics and biophysics of the cytoplasmic protein-protein complexes of the bacterial phosphoenolpyruvate sugar phosphotransferase system. Trends Biochem. Sci. 2013, 38, 515-530. [CrossRef] [PubMed]

15. Azuaga, A.I.; Neira, J.L.; Van Nuland, N.A. HPr as a model protein in strcuture, interaction, folding and stability studies. Protein Pep Lett. 2005, 12, 123-137. [CrossRef] [PubMed]

16. Gross, C.A.; Chan, C.; Dombroski, A.; Gruber, T.; Sharp, M.; Tupy, J.; Young, B. The functional and regulatory roles of sigma factors in transcription. Cold Spring Harbour Symp. Quant. Biol. 1998, 63, 141-155. [CrossRef]

17. Campbell, E.A.; Muzzin, O.; Chlenov, M.; Sun, J.L.; Anders Olson, C.; Weinman, O.; Trester-Zedlitz, M.L.; Darst, S.A. Structure of the bacterial RNA polymerase promoter specificity $\sigma$ factor. Mol. Cell 2002, 9, 527-539. [CrossRef]

18. Gruber, T.M.; Gross, C.A. Multiple sigma subunits and the portioning of bacterial transcription space. Annu. Rev. Microbiol. 2003, 57, 441-466. [CrossRef]

19. Ishihama, A. Functional modulation of Escherichia coli RNA polymerase. Annu. Rev. Microbiol. 2000, 54, 499-518. [CrossRef]

20. Jishage, M.; Ishihama, A. A stationary phase protein in Escherichia coli with binding activity to the major sigma subunit of RNA polymerase. Proc. Natl. Acad. Sci. USA 1998, 95, 4953-4958. [CrossRef]

21. Jishage, M.; Ishihama, A. Transcriptional organization and in vivo role of the Escherichia coli rsd gene, encoding the regulator of RNA polymerase sigma D. J. Bacteriol. 1999, 181, 3768-3776. [CrossRef] [PubMed]

22. Park, Y.H.; Lee, C.R.; Choe, M.; Seok, Y.K. HPr antagonizes the anti- $\sigma^{70}$ activity of Rsd in Escherichia coli. Proc. Natl. Acad. Sci. USA 2013, 110, 21142-21147. [CrossRef] [PubMed]

23. Park, Y.H.; Um, S.H.; Song, S.; Seok, Y.K.; Ha, N.C. Structural basis for the sequestration of the anti- $\sigma^{70}$ factor Rsd from $\sigma^{70}$ by the histidine-containing phosphocarrier protein HPr. Acta Crystallogr. D Biol. Crystallogr. 2015, 71, 1998-2008. [CrossRef] [PubMed]

24. Neira, J.L.; Hornos, F.; Cozza, C.; Cámara-Artigas, A.; Abián, O.; Velázquez-Campoy, A. The histidine phosphocarrier protein, $\mathrm{HPr}$, binds to the highly thermostable regulator of sigma D protein, Rsd, and its isolated helical fragments. Arch. Biochem. Biophys. 2018, 639, 26-37. [CrossRef] [PubMed]

25. Paget, S.B.; Hong, H.J.; Bibb, M.J.; Buttner, M.J. The ECF sigma factors of Streptomyces coelicolor A3(2). In SGM Symposium 61: Signals, Switches, Regulons and Cascades: Control of Bacterial Gene Expression; Hodgson, D.A., Thomas, C.M., Eds.; Cambridge University Press: Cambridge, UK, 2002; pp. 105-125.

26. Fernández-Ballester, G.; Maya, J.; Martin, A.; Parche, S.; Gómez, J.; Titgemeyer, F.; Neira, J.L. The histidine-phosphocarrier protein of Streptomyces coelicolor folds by a partially folded species at low pH. Eur. J. Biochem. 2003, 270, 2254-2267. [CrossRef]

27. Neira, J.L.; Gómez, J. The conformational stability of the Streptomyces coelicolor histidine-phosphocarrier protein. Characterization of cold denaturation and urea-protein interactions. Eur. J. Biochem. 2004, 271, 2165-2181. [CrossRef] 
28. Hurtado-Gómez, E.; Abián, O.; Muñoz, F.J.; Hernáiz, M.J.; Velázquez-Campoy, A.; Neira, J.L. Defining the epitope region of a peptide from the Streptomyces coelicolor phosphoenolpyruvate:sugar phosphotransferase system able to bind to the enzyme I. Biophys. J. 2008, 95, 1336-1348. [CrossRef]

29. Doménech, R.; Martínez-Gómez, A.I.; Aguado-Llera, D.; Martínez-Rodríguez, S.; Clemente-Jiménez, J.M.; Velázquez-Campoy, A.; Neira, J.L. Stability and binding of the phosphorylated species of the N-terminal domain of enzyme I and the histidine phosphocarrier protein from the Streptomyces coelicolor phosphoenolpyruvate:sugar phosphotransferase system. Arch. Biochem. Biophys. 2012, 526, 44-53. [CrossRef]

30. Hurtado-Gómez, E.; Caprini, M.; Prieto, A.; Neira, J.L. The helical structure propensity in the first helix of the histidine phosphocarrier protein of Streptomyces coelicolor. Protein Pep. Lett. 2007, 14, 281-290. [CrossRef]

31. Doménech, R.; Martínez-Rodríguez, S.; Velázquez-Campoy, A.; Neira, J.L. Peptides as inhibitors of the first phosphorylation step of the Streptomyces coelicolor phosphoenolpyruvate:sugar phosphotransferase system. Biochemistry 2012, 51, 7393-7402. [CrossRef]

32. Chakrabartty, A.; Kortemme, T.; Baldwin, R.L. Helix propensities of the amino acids measured in alanine-based peptides without helix-stabilizing side-chain interactions. Protein Sci. 1994, 3, 843-852. [CrossRef]

33. Woody, R.W. Circular dichroism. Methods Enzymol. 1995, 246, 34-71.

34. Kelly, S.M.; Jess, T.J.; Price, N.C. How to study proteins by circular dichroism. Biochim. Biophys. Act. Proteins Proteom. 2005, 1751, 119-139. [CrossRef]

35. Kelly, S.M.; Price, N.C. The use of circular dichroism in the investigation of protein structure and function. Curr. Prot. Pept. Sci. 2000, 1, 349-384. [CrossRef]

36. Chen, Y.H.; Yang, J.T.; Chaun, K.H. Determination of the helix and $\beta$ form of proteins in aqueous solution by circular dichroism. Biochemistry 1974, 13, 3350-3359. [CrossRef]

37. Sancho, J.; Neira, J.L.; Fersht, A.R. An N-terminal fragment of barnase has residual helical structure similar to that in a refolding intermediate. J. Mol. Biol. 1992, 224, 749-758. [CrossRef]

38. Jasanoff, A.; Fersht, A.R. Quantitative determination of helical propensities from trifluoroethanol titration curves. Biochemistry 1994, 33, 2129-2135. [CrossRef] [PubMed]

39. Best, R.B.; Buchete, N.V.; Hummer, G. Are current molecular dynamics force fields too helical? Biophys. J. 2008, 95, L07-L09. [CrossRef]

40. Piana, S.; Donchev, A.G.; Robustelli, P.; Shaw, D.E. Water dispersion interactions strongly influence simulated structural properties of disordered protein states. J. Phys. Chem. B 2015, 119, 5113-5123. [CrossRef] [PubMed]

41. Jorgensen, W.L.; Chandrasekhar, J.; Madura, J.D.; Impey, R.W.; Klein, M.L. Comparison of simple potential functions for simulating liquid water. J. Chem. Phys. 1983, 79, 926-935. [CrossRef]

42. Wilkins, D.K.; Grimshaw, S.B.; Receveur, V.; Dobson, C.M.; Jones, J.A.; Smith, L.J. Hydrodynamic radii of native and denatured proteins measured by pulse field gradient NMR techniques. Biochemistry 1999, 38, 16424-16431. [CrossRef] [PubMed]

43. Danielsson, J.; Jarvet, J.; Damberg, P.; Gräslund, A. Translational diffusion measured by PFG-NMR on full length and fragments of the Alzheimer $A \beta(1-40)$ peptide. Determination of the hydrodynamic radii of random coil peptide of varying length. Magn. Reson. Chem. 2002, 40, S89-S97. [CrossRef]

44. Neira, J.L.; Palomino_Schätzlein, M.; Hurtado-Gómez, E.; Ortore, M.G.; Falcó, A. An N-terminal half fragment of the histidine phosphocarrier protein, HPr, is disordered but binds to HPr partners and shows antibacterial properties. Biochim. Biophys. Acta Genral Subjects. 2021, 1865, 130015. [CrossRef]

45. Borcherds, W.; Theillet, F.-X.; Katzer, A.; Finzel, A.; Mishall, K.M.; Powell, A.T.; Wu, H.; Manieri, W.; Dieterich, C.; Selenko, P.M.; et al. Disorder and residual helicity alter p53-Mdm2 binding affinity and signalling in cells. Nat. Chem. Biol. 2014, 10, 1000-1002. [CrossRef] [PubMed]

46. Del Álamo, M.; Neira, J.L.; Mateu, M.G. The rmodynamic dissection of a low affinity protein-protein interface involved in human immunodeficiency virus assembl. J. Biol. Chem. 2003, 278, 27923-27929. [CrossRef]

47. Fischbach, M.A.; Walsh, C.T. Antibiotics for emerging pathogens. Science 2009, 325, 1089-1093. [CrossRef] [PubMed]

48. Gill, S.C.; von Hippel, P.H. Calculation of protein extinction coefficients from amino acid sequence data. Anal. Biochem. 1989, 182, 319-326. [CrossRef]

49. Miroux, B.; Walker, J.E. Over-production of proteins in Escherichia coli: Mutant hosts that allow synthesis of some membrane proteins and globular proteins at high levels. J. Mol. Biol. 1996, 260, 289-298. [CrossRef]

50. Yuan, A.H.; Gregory, B.D.; Sharp, J.S.; McCleary, K.; Dove, S.L.; Hochschild, A. Rsd family proteins make simultaneous interactions with regions 2 and 4 of the primary sigma factor. Mol. Microbiol. 2008, 70, 1136-1151. [CrossRef]

51. Beckett, D. Measurement and analysis of equilibrium binding titrations: A beginner's guide. Methods Enzymol. 2011, 488, 1-16.

52. Royer, C.A.; Scarlatta, S.F. Fluorescence approaches to quantifying biomolecular interactions. Methods Enzymol. 2008, 450, 79-106. [PubMed]

53. Birdsall, B.; King, R.W.; Wheeler, M.R.; Lewis, C.A., Jr.; Goode, S.; Dunlap, R.B.; Roberts, G.C. Correction for light absorption in fluorescence studies of protein-ligand interactions. Anal. Biochem. 1983, 132, 353-361. [CrossRef]

54. Czypionka, A.; de los Paños, O.R.; Mateu, M.G.; Barrera, F.N.; Hurtado-Gómez, E.; Gómez, J.; Vidal, M.; Neira, J.L. The isolated Cterminal domain of Ring 1B is a dimer made of stable, well-structured monomers. Biochemistry 2007, 46, 12764-12776. [CrossRef] [PubMed] 
55. Cavanagh, J.; Fairbrother, W.J.; Palmer, A.G.; Skelton, N.J. Protein NMR Spectroscopy: Principles and Practice; Academic Press: New York, NY, USA, 1996.

56. Marion, D.; Wüthrich, K. Application of phase sensitive two-dimensional correlated spectroscopy (COSY) for measurements of 1H-1H spin-spin coupling constants in proteins. Biochem. Biophys. Res. Commun. 1983, 11, 967-974. [CrossRef]

57. Bax, A.; Davis, D.G. MLEV-17-based two-dimensional homonuclear magnetization transfer spectroscopy. J. Magn. Reson. 1985, 65, 355-360. [CrossRef]

58. Piotto, M.; Saudek, V.; Sklenar, V. Gradient-tailored excitation for single-quantum NMR spectroscopy of aqueous solutions. J. Biomol. NMR 1992, 2, 661-675. [CrossRef]

59. Kumar, A.; Ernst, R.R.; Wüthrich, K. A two-dimensional nuclear Overhauser enhancement (2D NOE) experiment for the elucidation of complete proton-proton cross-relaxation networks in biological macromolecules. Biochem. Biophys. Res. Commun. 1980, 95, 1-6. [CrossRef]

60. Bax, A.; Davis, D.G. Practical aspects of two-dimensional transverse NOE spectroscopy. J. Magn. Reson 1985, 63, 207-213. [CrossRef]

61. Wüthrich, K. NMR of Proteins and Nucleic Acids; John Wiley and Sons: New York, NY, USA, 1986.

62. Schwarzinger, S.; Kroon, G.J.; Foss, T.R.; Chung, J.; Wright, P.E.; Dyson, H.J. Sequence-dependent correction of random coil NMR chemical shifts. J. Am. Chem. Soc. 2001, 123, 2970-2978. [CrossRef]

63. Santofimia-Castaño, P.; Xia, Y.; Lan, W.; Zhou, Z.; Huang, C.; Peng, L.; Soubeyran, P.; Velazquez-Campoy, A.; Abian, O.; Rizzuti, B.; et al. Ligand-based design identifies a potent NUPR1 inhibitor exerting anticancer activity via necroptosis. J. Clin. Investig. 2019, 129, 2500-2513. [CrossRef] [PubMed]

64. Neira, J.L.; Rizzuti, B.; Iovanna, J.L. Determinants of the $\mathrm{p} K_{\mathrm{a}}$ values of ionizable residues in an intrinsically disordered protein. Arch. Biochem. Biophys. 2016, 598, 18-27. [CrossRef]

65. Santofimia-Castaño, P.; Rizzuti, B.; Abián, O.; Velázquez-Campoy, A.; Iovanna, J.L.; Neira, J.L. Amphipathic helical peptides hamper protein-protein interactions of the intrinsically disordered chromatin nuclear protein 1 (NUPR1). Biochim. Biophys. Act. Gen. Subjects 2018, 1862, 1283-1295. [CrossRef]

66. Lindorff-Larsen, K.; Piana, S.; Palmo, K.; Maragakis, P.; Klepeis, J.L.; Dror, R.O.; Shaw, D.E. Improved side-chain torsion potentials for the Amber ff99SB protein force field. Proteins 2010, 78, 1950-1958. [CrossRef]

67. Schumacher, M.A.; Allen, G.S.; Diel, M.; Seidel, G.; Hillen, W.; Brennan, R.G. Structural basis for allosteric control of the transcription regulator CcpA by the phosphoprotein HPr-Ser46-P. Cell 2004, 118, 731-741. [CrossRef] [PubMed]

68. Neira, J.L.; Correa, J.; Rizzuti, B.; Santofimia-Castaño, P.; Abian, O.; Velázquez-Campoy, A.; Fernández-Megía, E.; Iovanna, J.L. Dendrimers as competitors of protein-protein interactions of the intrinsically disordered nuclear chromatin protein NUPR1. Biomacromolecules 2019, 20, 2567-2576. [CrossRef] [PubMed]

69. Rocca, C.; Grande, F.; Granieri, M.C.; Colombo, B.; De Bartolo, A.; Giordano, F.; Rago, V.; Amodio, N.; Tota, B.; Cerra, M.C.; et al. The chromogranin $\mathrm{A}_{1-373}$ fragment reveals how a single change in the protein sequence exerts strong cardioregulatory effects by engaging neuropilin-1. Acta Physiol. 2021, 231, e13570. [CrossRef] [PubMed]

70. Cockerill, F.R.; Wikler, M.; Alder, J.; Dudley, M.; Eliopoulos, G.; Ferraro, M.; Hardy, D.; Hecht, D.; Hindler, J.; Patel, J. Methods for dilution antimicrobial susceptibility tests for bacteria that grow aerobically: Approved standard. Clin. Lab. Stand. Inst. 2012, 32, M07-A09.

71. Mira, A.; Sainz-Urruela, C.; Codina, H.; Jenkins, S.I.; Rodríguez-Díaz, J.C.; Mallavia, R.; Falco, A. Physico-chemically distinct nanomaterials synthesized from derivates of a poly (anhydride) diversify the spectrum of loadable antibiotics. Nanomaterials 2020, 10, 486. [CrossRef] 